\title{
Perception of Trainers and Trainees on the Apprenticeship System of Furniture Making in Edo State, Nigeria
}

\author{
Jane Itohan Oviawe ${ }^{1}$, Samuel C. O. A. Ezeji ${ }^{2}$, Raymond Uwameiye ${ }^{1}$ \\ ${ }^{1}$ Department of Vocational and Technical Education, Faculty of Education, Ambrose Alli University, Ekpoma, Nigeria \\ ${ }^{2}$ Department of Industrial Technical Education, Faculty of Vocational Teacher Education, University of Nigeria, Nuskka, Nigeria
}

\section{Email address:}

janeoviawe@aauekpoma.edu.ng (J. I. Oviawe), janeoviawe98@gmail.com (J. I. Oviawe), scoaezeji@yahoo.com (S. C. O. A. Ezeji), uwaray56@yahoo.com (R. Uwameiye)

\section{To cite this article:}

Jane Itohan Oviawe, Samuel C. O. A. Ezeji, Raymond Uwameiye. Perception of Trainers and Trainees on the Apprenticeship System of Furniture Making in Edo State, Nigeria. International Journal of Vocational Education and Training Research.

Vol. 3, No. 3, 2017, pp. 21-28. doi: 10.11648/j.ijvetr.20170303.11

Received: May 1, 2017; Accepted: May 25, 2017; Published: June 30, 2017

\begin{abstract}
This study investigated the state of the apprenticeship system of furniture making in Edo State using a simple survey research design. The population comprised of all the 650 trainers and 1,400 trainees engaged in apprenticeship in furniture-making in Edo State of Nigeria. The sample consisted of 500 trainers and 1000 trainees randomly drawn from the population. A 74-item questionnaire was the instrument used for data collection. Mean, Standard Deviation and t-test were statistical tools used for data analysis. Findings include among others narrow content, untrained trainers, lack of facilities and equipment, poor funding, lack of support from government; trainees involved in domestic activities, and workshops not accredited. It was recommended among others that re-training programmes should be organized for trainers by government, industries, and non-governmental agencies and organizations and trainees should not be used as domestic servants.
\end{abstract}

Keywords: Apprenticeship, Furniture-Making, Trainers and Trainees

\section{Introduction}

Furniture-making is one of the occupations in the woodworking industry. It involves designing, smoothing and leveling, cutting, arranging, assembling and finishing of different components of a wood piece. Furniture-making is a very lucrative business that affords individuals enormous opportunities for employment and self-development through the acquisition of saleable construction skills. Acquisition of saleable construction skills in furniture-making is important in order to equip individuals for self-employment. Such trainings are majorly out-of schools as apprenticeship training.

Apprenticeship, according to Ali \& Okorie (2000) is the training in art, trade or craft under a legal agreement defining the relationship between the master/trainer and the learner/trainee as well as the duration of their relationship. It is one of the most effective methods of training skilled workers. Apprenticeship is a system of learning skills of a craft or trade from experts in the field by working with them for a set period of time. Apprenticeship is a traditional or an informal method of acquiring skills in most developing countries. Today, things are changing, today's realities make it obvious to all classes of people that skills acquisition through apprenticeship is the solution for future self-reliance, sustainability and development. Apprenticeship system offers opportunity for young people to gain the strong vocational skills and knowledge required to build lasting and meaningful careers for self-employment and self-reliance (Famiwole, Oke \& Amadi, 2012). Apprenticeship is a procedure by which an individual acquires skills necessary to be proficient in a trade or craft, under the tutelage of a master practitioner for a period of time.

Apprenticeship is the process of learning or skills acquisition through enlistment with a master craftsman (Adekola, 2013). According to Olateju (2001), apprenticeship is any system by which an employer or trainer undertakes by contract, written or implied an apprentice or trainee, to train him or her systematically for a trade or occupation for a period, which has been fixed in advance and in the course of which the apprentice agrees to work in the employer's service (Musa, 2010). 
An apprentice is one bound by legal agreement to work for another for a specific amount of time in return for instruction in a trade, art or business, or anyone who is learning a trade (Erica, 2012). It is a method of developing craftsmen. Apprenticeship is an important method of learning skilled work in the United States, Canada, Germany and other developed countries. The importance of apprenticeship according to Burns (2009), include among others: (i) provision of paid jobs not cheap labour; (ii) provision of job opportunities for young people (iii) offers opportunity for continued wages and job security upon completion of training; (iv) early self-reliance and financial independence for younger people; (v) offer of competence in specific trades that is cheaper than the classroom can offer; and (vi) rate of pay increases with knowledge and ability. The ultimate aim of apprenticeship is the acquisition of skills for survival and self-sustenance.

Skill acquisition in furniture-making is one of the surest ways through which individuals can find their way into the labour market either in the private or public sector. Mogaji (1998) in Akubue (2009) defined a skill as an activity involving knowledge, judgment, accuracy and usually manual dexterity, all of which are acquired as a result of long training and practice. In Edo State, apprenticeship training is still recognized as one of the oldest forms of organized methods of providing skill training to the youths and adults (Okoro, 1999). It involves an arrangement under which a youth or an adult, male or female bonds himself or herself to serve and learn for a definite period of time from a master craftsman who, on his or her side covenants to teach his or her trade, craft or skill to the learner or apprentice (Okorie \& Ezeji, 1988). Apprenticeship training in furniture-making is, therefore, a training contract or agreement between a trainer and trainee on the skills involved in furniture construction and production for a given period of time. It is a form of onthe-job training which entails the different aspects of furniture-making in which the trainee will acquire the needed skills and knowledge to be proficient in it. Apprenticeship system of training in furniture-making is mainly practicaloriented and on-the-job. The trainee learns as he works for the master or trainer. At the same time, the trainer gains from the services of the trainee. The methods of acquiring skills and knowledge are through imitation, repetition, and active participation (Ochiagha, 1995). Osuala (1998) in Okorie (2000) stated that apprenticeship may be necessary if an entrepreneur intends to set up a small business. Braide (2003) asserted that experience, which is a fundamental basis in developing and shaping creativity can be obtained through apprenticeship.

Apprenticeship training in furniture-making has been useful in equipping many youths with skills for successful living. This type of training exists in both rural and urban areas in Edo State. Majority of individuals who engage in it are mainly primary and secondary school drop-outs (Okorie \& Ezeji. 1988). In Edo State, there is high concentration of male apprentices in furniture-making. Osuala (1998) in Okorie (2000) posited that in apprenticeship system, instruction is neither institutionalized nor compartmentalized. There is no content for instruction. The furniture items produced through apprenticeship are influenced by taste of consumer, availability of raw materials, pattern in-vogue, and economic conditions.

Apprenticeship training in furniture-making has been a very useful form of education which has favoured the economic growth and social development of youths and adults in Edo State. It has led to the production of many furnishing items both for local and international consumption. Acquiring psycho-productive skills in furniture-making has significant importance to national development and economic growth of the nation. Mercer (1979) in Okorie \& Ezeji (1988) averred that the skills acquired through apprenticeship system are useful in the following ways: (i) they provide financial and psychological security to the trainees after graduation; (ii) the master trainer benefits from productive services of the apprentices during their training; and (iii) the society at large, receives continuous supplies of skilled labour in furnituremaking and quality goods.

However, despite the tremendous roles apprenticeship training in furniture-making is playing in job creation and revenue generation, many problems are still hindering the realization of its objectives in Edo State. Hence, the need to assess the apprenticeship system of furniture-making in Edo State in terms of its current state; the problems identified and to evolve ways of solving the problems.

\section{Purpose of the Study}

The main purpose of this study was to find out the perception of Trainers and Trainees on the apprenticeship system of furniture-making in Edo State. Specifically, this study sought to find out:

1. the current state of non-formal apprenticeship system of furniture-making in Edo State;

2. the problems trainers and trainees in furniture-making encounter in apprenticeship system in Edo State; and

3. measures of revamping the apprenticeship system of furniture-making in Edo State.

\section{Method of Study}

The research design adopted in this study was a survey on assessment of the apprenticeship system of furniture-making in Edo State of Nigeria.

The target population for this study consisted of 2,050 furniture makers and their apprentices in Edo State of Nigeria. The population consisted of 650 trainers and 1,400 trainees or apprentices in furniture-making in Edo State. These trainees were mainly youths and predominantly males, with their ages ranging from 18 to 30 years. Simple random sampling technique was used in selecting 500 trainers and 1000 trainees, which represented $73.1 \%$ of the population.

The instrument used for data collection was the researchers developed 70-item structured questionnaire with a five-point Likert scale response options as follows: Strongly Agree 
(SA) - 5; Agree (A) - 4; Undecided (UD) - 3; Disagree (D) -2 , and Strongly Disagree (SD) -1 .

The instrument was validated by three academic staff from the Department of Vocational and Technical Education, Ambrose Alli University, Ekpoma. Their suggestions and corrections resulted in the final draft used for this study.

To determine the reliability of the instrument, a test-retest method was used on 20 respondents within the study population but who were not part of the sample. Cronbach's Alpha reliability index was used to derive the reliability coefficient of 0.84 . A total of 1,500 copies of the questionnaire were administered personally on the respondents with the help of five research assistants. On the whole, 1,470 copies of the questionnaire were collected representing 98 per cent return rate, all these were used for data analysis.

The data collected for this study were analysed using Mean (X) and t-test statistics. The Mean of 3.50 was taken as the cut off point for decision such that a Mean response that falls below 3.50 was regarded as Disagree, while a Mean response equal to or over 3.50 was regarded as Agree. With respect to the null hypotheses, any calculated t-test value less than $1.96(\mathrm{P}<.05)$ was regarded as not significant, while any calculated t-test value above 1.96 at.05 level of significance $(\mathrm{P}>.05)$ was regarded as significant.

\section{Results}

Research Question 1: What is the current state of apprenticeship system of furniture-making in EdoState?

Table 1. The Current State of Apprenticeship System of Furniture-making.

\begin{tabular}{|c|c|c|c|c|}
\hline $\mathbf{S} / \mathbf{N}$ & Current state of apprenticeship system of furniture making & $\mathbf{X}$ & SD & Remarks \\
\hline 1 & There is good relationship between trainers and trainees & 4.34 & 0.95 & Agree \\
\hline 2 & Trainees learn by watching imitating the trainer & 4.43 & 0.46 & Agree \\
\hline 3 & The trainers usually undergo skill development training & 2.09 & 0.91 & Disagree \\
\hline 4 & There is regular curriculum used for training & 1.93 & 1.47 & Disagree \\
\hline 5 & The instructions proceed from simple to complex & 2.46 & 0.70 & Disagree \\
\hline 6 & Trainees are usually involved in domestic activities & 4.17 & 0.74 & Agree \\
\hline 7 & Trainees learn by participating in the art & 4.61 & 0.56 & Agree \\
\hline 9 & Trainees are taught the causes of problems before correcting it & 2.29 & 0.81 & Disagree \\
\hline 10 & Trainees are taught safety precautions in furniture-making workshop & 4.43 & 0.64 & Agree \\
\hline 11 & The trainees received theoretical knowledge of furniture-making & 1.93 & 1.08 & Disagree \\
\hline 12 & There is cooperation between non-formal apprenticeship system and technical institutions & 1.93 & 0.98 & Disagree \\
\hline 13 & Children of less than 18 are usually accepted as trainees & 4.41 & 0.54 & Agree \\
\hline 14 & Workshops are usually accredited before admission of trainees & 1.87 & 0.97 & Disagree \\
\hline 15 & The graduation of trainees is based on examination & 2.46 & 0.72 & Disagree \\
\hline 16 & Trainees upon graduation are issued certificates & 4.71 & 0.84 & Agree \\
\hline
\end{tabular}

In response to research question 1, Table 1 reveals that all the respondents agreed with seven items out of the 17 items with Mean scores ranging from 4.17 to 4.71 and disagreed with the other 10 items with Mean scores ranging from 1.87

\section{to 2.46 .}

Research Question 2: What arethe problems trainers and trainees encounter in furniture making apprenticeship programmes in Edo State?

Table 2. Mean Ratings of Respondents on their Perception on the Trainer/Trainee Related Problems to Apprenticeship System of Furniture-making.

\begin{tabular}{|c|c|c|c|c|}
\hline $\mathbf{S} / \mathbf{N}$ & Items/Problems & $\mathbf{X}$ & SD & Remarks \\
\hline 1 & Poor educational background of trainers & 4.37 & 0.65 & Agree \\
\hline 2 & Trainers not qualified for the teaching role assigned to them & 4.05 & 0.77 & Agree \\
\hline 3 & Trainers hide skills from trainees & 3.86 & 0.32 & Agree \\
\hline 4 & Lack of finances for trainees while in training & 4.03 & 0.63 & Agree \\
\hline 5 & No opportunity for up-dating the knowledge and skill possessed by trainers & 3.46 & 1.07 & Agree \\
\hline 6 & Poor teaching method & 3.70 & 0.54 & Agree \\
\hline 7 & Short training period relative to what is to be learnt & 2.59 & 0.74 & Disagree \\
\hline 8 & Some trainees exhibit truant behaviour & 4.31 & 0.68 & Agree \\
\hline 9 & Bias for male gender (only good and meant for males) & 3.46 & 1.10 & Agree \\
\hline 10 & Lack of genuine interest and commitment in the training by trainees & 2.16 & 0.81 & Disagree \\
\hline 11 & Trainees not regular at training & 4.04 & 0.52 & Agree \\
\hline 12 & Lack of fund during and after training & 3.75 & 1.12 & Agree \\
\hline 13 & Haphazard learning of the skills by some trainees & 4.00 & 0.92 & Agree \\
\hline 14 & Difficulty in understanding due to illiteracy & 3.66 & 0.95 & Agree \\
\hline 15 & Lack of commitment of trainers to trainees & 4.39 & 0.66 & Agree \\
\hline 17 & Inadequate encouragement from government & 3.56 & 1.12 & Agree \\
\hline 18 & Lack of personnel to supervise training & 3.76 & 0.48 & Agree \\
\hline 19 & $\begin{array}{l}\text { Inadequate public enlightenment on the importance of apprenticeship training in furniture } \\
\text { making by the government }\end{array}$ & 3.69 & 0.36 & Agree \\
\hline 20 & No provision made by government for re-training of trainers & 3.57 & 0.79 & Agree \\
\hline
\end{tabular}




\begin{tabular}{lllll}
\hline S/N & Items/Problems & X & SD & Remarks \\
\hline 21 & Inadequate facilities and equipment for training and learning & 3.57 & 0.88 & Agree \\
22 & Inadequate of power supply & 3.71 & 0.54 & Agree \\
23 & Lack of adequate textbooks on furniture-making & 3.51 & 0.65 & Agree \\
24 & Unavailability of spare parts of some equipment in the market & 2.31 & 0.91 & Disagree \\
25 & High cost of equipment and facilities & 3.67 & 0.58 & Agree \\
26 & Poor maintenance of available facilities and equipment & 3.53 & 0.61 & Agree \\
27 & Lack of space in trainers workshop & 2.57 & 0.84 & Disagree \\
28 & Lack of organized syllabus for apprenticeship training in furniture making. & 3.58 & 0.52 & Agree \\
29 & Poor theoretical content & 4.20 & 0.78 & Agree \\
30 & Shallow content & 4.04 & 0.54 & Agree \\
31 & Unsystematic content & 4.11 & 0.71 & Agree \\
32 & Out-dated content & 3.60 & 0.82 & Agree \\
\hline
\end{tabular}

In response to research question 2, Table 2 reveals that all the respondents agreed that 28 out of the 32 items are problems trainers and trainees encounter in furniture-making apprenticeship with mean scores ranging from 4.00 to 439 ; but disagreed with four of the items. This implies that the respondents perceived the 32 items as problems militating against apprenticeship training in furniture-making.

Research Question 3: What are the strategiesfor revamping the apprenticeship system of furniture making in Edo State?

Table 3. Strategiesof Revamping the Apprenticeship System of Furniture-making.

\begin{tabular}{|c|c|c|c|c|}
\hline S/No & Strategies & $\mathbf{X}$ & SD & Remarks \\
\hline 1 & Trainers should be encouraged to go for continuing education & 4.49 & 1.14 & Agree \\
\hline 2 & Appropriate instructional methods should be adopted for the training & 4.20 & 0.90 & Agree \\
\hline 3 & Simplify teaching methods by use of instruments & 3.75 & 1.10 & Agree \\
\hline 4 & Trainees should be assisted with loans during and after training & 4.44 & 0.95 & Agree \\
\hline 5 & Graduates of apprenticeship training should be helped by government to establish on their own & 3.91 & 1.21 & Agree \\
\hline 6 & Training period should not be fixed but depend on progress made by trainee & 4.00 & 1.18 & Agree \\
\hline 7 & Need for more public enlightenment on the importance of apprenticeship training in furniture-making & 4.20 & 0.92 & Agree \\
\hline 8 & Arouse trainee interest by awarding gifts & 3.71 & 1.23 & Agree \\
\hline 9 & Adequate and modern facilities should be provided for training and learning & 3.76 & 0.48 & Agree \\
\hline 10 & Public libraries should be equipped with books on furniture making & 3.87 & 0.58 & Agree \\
\hline 11 & Government should provide support for the programme & 3.88 & 1.21 & Agree \\
\hline 12 & Government should organize avenues to train and update the skills possessed by trainers & 3.70 & 0.46 & Agree \\
\hline 13 & Qualified personnel should be assigned to supervise the training programme & 3.88 & 0.90 & Agree \\
\hline 14 & Available facilities should be adequately cared for & 3.71 & 0.64 & Agree \\
\hline 15 & The workshops should be accredited by NBTE/NDE before the trainers are allowed to accept apprentices & 4.43 & 0.88 & Agree \\
\hline 17 & The programme should be publicized and highly encouraged by government to stop stigmatization & 3.90 & 0.64 & Agree \\
\hline 18 & There should be cooperation between apprenticeship and technical institutions & 3.87 & 0.92 & Agree \\
\hline 19 & Trainees should be subjected to examination before graduation & 3.96 & 0.71 & Agree \\
\hline 20 & There should be constant supervision of the programme by the Government & 3.71 & 1.12 & Agree \\
\hline 21 & Trainers should ensure the method of instruction is from simple to complex & 4.03 & 1.00 & Agree \\
\hline 22 & Trainees should not be involved in domestic activities & 2.27 & 0.90 & Disagree \\
\hline 23 & There should be cordial relationship between trainers and trainees & 4.37 & 0.61 & Agree \\
\hline 24 & Trainees should be taught the cause of problem before correcting it & 4.08 & 0.90 & Agree \\
\hline 25 & $\begin{array}{l}\text { Government should organize refreshing courses for Trainers on regularly basis to update learning in } \\
\text { vocational centres }\end{array}$ & 3.87 & 0.92 & Agree \\
\hline
\end{tabular}

In response to research question 3, Table 3 shows that all the respondents agreed that 24 out of the 25 items are strategies for revamping the apprenticeship system of furniture-making. The Mean scores ranged from 3.70 to 4.49; while item 22 which was rated as disagreed had a Mean score

\section{of 2.27}

Hypothesis 1: There is no significant difference between the mean ratings of the perceptions of trainers and trainees on the current state of apprenticeship system of furnituremaking in Edo State.

Table 4. Respondents Mean Ratings, Standard Deviations and t-test values on the current state of Apprenticeship system of Furniture making in Edo State.

\begin{tabular}{|c|c|c|c|c|c|c|c|c|}
\hline \multirow{2}{*}{ S/No. } & \multicolumn{3}{|c|}{ Trainers } & \multicolumn{3}{|c|}{ Trainees } & \multirow{2}{*}{$\begin{array}{l}\text { Calculated } \\
\text { t-test value }\end{array}$} & \multirow{2}{*}{ Remarks } \\
\hline & $\mathrm{N}_{1}$ & $X_{1}$ & $\mathrm{SD}_{1}$ & $\mathbf{N}_{2}$ & $\mathbf{X}_{2}$ & $\mathrm{SD}_{2}$ & & \\
\hline 1 & 500 & 4.47 & 0.95 & 1000 & 4.21 & 0.58 & -0.41 & Not Significant \\
\hline 2 & 500 & 4.82 & 0.46 & 1000 & 4.07 & 1.39 & -0.30 & Not Significant \\
\hline 3 & 500 & 2.03 & 0.91 & 1000 & 2.15 & 0.78 & 0.42 & Not Significant \\
\hline 4 & 500 & 2.01 & 1.08 & 1000 & 1.84 & 1.32 & 1.47 & Not Significant \\
\hline 5 & 500 & 2.61 & 1.34 & 1000 & 2.81 & 1.07 & -1.45 & Not Significant \\
\hline
\end{tabular}




\begin{tabular}{|c|c|c|c|c|c|c|c|c|}
\hline \multirow{2}{*}{ S/No. } & \multicolumn{3}{|c|}{ Trainers } & \multicolumn{3}{|c|}{ Trainees } & \multirow{2}{*}{$\begin{array}{l}\text { Calculated } \\
\text { t-test value }\end{array}$} & \multirow{2}{*}{ Remarks } \\
\hline & $\mathbf{N}_{1}$ & $\mathbf{X}_{1}$ & SD $_{1}$ & $\mathbf{N}_{2}$ & $\mathbf{X}_{2}$ & $\mathrm{SD}_{2}$ & & \\
\hline 6 & 500 & 4.13 & 1.14 & 1000 & 4.21 & 0.70 & -0.10 & Not Significant \\
\hline 7 & 500 & 4.85 & 0.36 & 1000 & 4.36 & 0.50 & -1.54 & Not Significant \\
\hline 8 & 500 & 2.37 & 1.09 & 1000 & 2.18 & 1.23 & 1.56 & Not Significant \\
\hline 9 & 500 & 2.49 & 0.38 & 1000 & 2.47 & 0.81 & 0.47 & Not Significant \\
\hline 10 & 500 & 4.43 & 0.64 & 1000 & 4.43 & 0.51 & -1.41 & Not Significant \\
\hline 11 & 500 & 1.93 & 1.32 & 1000 & 1.84 & 1.08 & 1.47 & Not Significant \\
\hline 13 & 500 & 4.45 & 0.54 & 1000 & 4.36 & 1.15 & -0.30 & Not Significant \\
\hline 14 & 500 & 1.87 & 0.97 & 1000 & 1.94 & 0.84 & 0.97 & Not Significant \\
\hline 15 & 500 & 2.41 & 0.72 & 1000 & 2.51 & 0.93 & 0.72 & Not Significant \\
\hline 16 & 500 & 4.85 & 0.36 & 1000 & 4.57 & 0.51 & -1.26 & Not Significant \\
\hline 17 & 500 & 1.90 & 0.58 & 1000 & 1.87 & 0.89 & 0.88 & Not Significant \\
\hline
\end{tabular}

In response to hypothesis 1 , Table 4 shows that significant difference does not exist between the mean ratings of trainers and trainees on the current state of apprenticeship system of furniture-making in Edo State. This implies that the calculated t-test value of all the items (17) are less than the criterion t-test value of 1.96 at 0.05 level of significance
( $P>0.05)$, thereby retaining the null hypothesis of no significant difference.

Hypothesis 2: There is no significant difference between the mean ratings of trainers and trainees on the problems encountered in furniture-making apprenticeship programmes in Edo State.

Table 5. Respondents Mean Ratings, Standard Deviations and t-test values on the Problems encountered in Furniture making Apprenticeship system in Edo State.

\begin{tabular}{|c|c|c|c|c|c|c|c|c|}
\hline \multirow{2}{*}{ S/No. } & \multicolumn{3}{|c|}{ Trainers } & \multicolumn{3}{|c|}{ Trainees } & \multirow{2}{*}{$\begin{array}{c}\text { Calculated } \\
\text { t-test value }\end{array}$} & \multirow[t]{2}{*}{ Remarks } \\
\hline & $\mathbf{N}_{1}$ & $\mathbf{X}_{1}$ & $\mathbf{S D}_{1}$ & $\mathbf{N}_{2}$ & $\mathbf{X}_{2}$ & $\mathrm{SD}_{2}$ & & \\
\hline 1 & 500 & 4.70 & 1.21 & 1000 & 4.03 & 0.65 & 1.21 & Not Significant \\
\hline 2 & 500 & 4.69 & 0.36 & 1000 & 3.40 & 0.70 & 1.25 & Not Significant \\
\hline 3 & 500 & 3.05 & 0.10 & 1000 & 4.67 & 0.30 & 0.85 & Not Significant \\
\hline 4 & 500 & 4.00 & 1.39 & 1000 & 4.06 & 0.63 & 0.50 & Not Significant \\
\hline 5 & 500 & 3.61 & 1.34 & 1000 & 3.81 & 1.07 & -1.45 & Not Significant \\
\hline 6 & 500 & 3.68 & 0.54 & 1000 & 3.71 & 0.38 & 1.00 & Not Significant \\
\hline 7 & 500 & 2.56 & 0.72 & 1000 & 2.61 & 0.93 & 0.72 & Not Significant \\
\hline 8 & 500 & 4.75 & 0.60 & 1000 & 3.86 & 0.40 & 0.34 & Not Significant \\
\hline 9 & 500 & 3.61 & 1.34 & 1000 & 3.81 & 1.07 & 1.45 & Not Significant \\
\hline 10 & 500 & 2.28 & 0.89 & 1000 & 2.06 & 0.77 & 1.02 & Not Significant \\
\hline 11 & 500 & 4.68 & 0.45 & 1000 & 3.40 & 0.55 & 1.15 & Not Significant \\
\hline 12 & 500 & 3.81 & 1.23 & 1000 & 3.69 & 1.04 & 1.04 & Not Significant \\
\hline 13 & 500 & 4.35 & 0.96 & 1000 & 3.65 & 1.14 & 0.87 & Not Significant \\
\hline 14 & 500 & 4.26 & 1.15 & 1000 & 3.06 & 0.45 & 1.26 & Not Significant \\
\hline 16 & 500 & 3.68 & 0.78 & 1000 & 3.46 & 0.90 & 0.98 & Not Significant \\
\hline 17 & 500 & 3.70 & 1.12 & 1000 & 3.45 & 1.15 & 0.66 & Not Significant \\
\hline 18 & 500 & 3.77 & 0.36 & 1000 & 3.75 & 0.69 & 0.53 & Not Significant \\
\hline 19 & 500 & 3.66 & 0.38 & 1000 & 3.72 & 0.34 & 0.36 & Not Significant \\
\hline 20 & 500 & 3.74 & 0.65 & 1000 & 3.43 & 0.89 & 1.76 & Not Significant \\
\hline 21 & 500 & 3.46 & 0.90 & 1000 & 3.68 & 0.78 & 0.98 & Not Significant \\
\hline 22 & 500 & 3.86 & 0.36 & 1000 & 3.66 & 0.62 & 1.70 & Not Significant \\
\hline 23 & 500 & 3.43 & 0.69 & 1000 & 3.51 & 0.64 & 0.56 & Not Significant \\
\hline 24 & 500 & 2.14 & 0.98 & 1000 & 2.21 & 0.87 & 0.53 & Not Significant \\
\hline 25 & 500 & 3.95 & 0.22 & 1000 & 3.60 & 0.70 & 1.17 & Not Significant \\
\hline 26 & 500 & 3.55 & 0.67 & 1000 & 3.50 & 0.63 & 0.95 & Not Significant \\
\hline 27 & 500 & 2.68 & 0.78 & 1000 & 2.46 & 0.90 & 0.98 & Not Significant \\
\hline 28 & 500 & 3.70 & 0.47 & 1000 & 3.46 & 0.59 & 1.66 & Not Significant \\
\hline 29 & 500 & 4.34 & 0.96 & 1000 & 4.05 & 0.41 & 1.22 & Not Significant \\
\hline 32 & 500 & 3.70 & 0.78 & 1000 & 3.50 & 0.90 & 0.99 & Not Significant \\
\hline
\end{tabular}

In response to hypothesis 2 , Table 5 shows that significant difference does not exist between the mean ratings of trainers and trainees on the current state of apprenticeship system of furniture-making in Edo State. This means that the calculated t-test value of all the 32 items are less than the criterion t-test value of 1.96 at 0.05 level of significance $(P>0.05)$, thereby retaining the null hypothesis of no significant difference.

Hypothesis 3: There is no significant difference between the mean ratings of trainers and trainees on the strategies for revamping the apprenticeship system of furniture-making in 
Edo State.

Table 6. Respondents Mean Ratings, Standard Deviations and t-test values on the strategies for revamping the Apprenticeship system of Furniture making in Edo State.

\begin{tabular}{|c|c|c|c|c|c|c|c|c|}
\hline \multirow[t]{2}{*}{ S/No. } & \multicolumn{3}{|c|}{ Trainers } & \multicolumn{3}{|c|}{ Trainees } & \multirow{2}{*}{$\begin{array}{l}\text { Calculated } \\
\text { t-test value }\end{array}$} & \multirow[t]{2}{*}{ Remarks } \\
\hline & $\mathbf{N}_{1}$ & $X_{1}$ & $\mathrm{SD}_{1}$ & $\mathbf{N}_{2}$ & $\mathrm{X}_{2}$ & $\mathrm{SD}_{2}$ & & \\
\hline 1 & 500 & 4.17 & 1.10 & 1000 & 4.80 & 1.41 & 0.67 & Not Significant \\
\hline 2 & 500 & 4.34 & 0.96 & 1000 & 4.05 & 0.41 & 1.17 & Not Significant \\
\hline 3 & 500 & 3.81 & 1.23 & 1000 & 3.69 & 1.04 & 1.04 & Not Significant \\
\hline 4 & 500 & 4.74 & 1.01 & 1000 & 4.13 & 0.64 & 1.19 & Not Significant \\
\hline 5 & 500 & 4.11 & 1.36 & 1000 & 3.71 & 1.15 & 0.27 & Not Significant \\
\hline 6 & 500 & 4.09 & 1.39 & 1000 & 3.90 & 1.07 & 0.65 & Not Significant \\
\hline 7 & 500 & 4.34 & 0.96 & 1000 & 4.05 & 0.41 & 1.17 & Not Significant \\
\hline 8 & 500 & 3.56 & 1.31 & 1000 & 3.86 & 1.21 & 1.38 & Not Significant \\
\hline 9 & 500 & 3.77 & 0.36 & 1000 & 3.75 & 0.69 & 0.53 & Not Significant \\
\hline 10 & 500 & 3.88 & 0.61 & 1000 & 3.86 & 0.11 & 0.40 & Not Significant \\
\hline 11 & 500 & 3.93 & 1.23 & 1000 & 3.83 & 1.27 & 0.82 & Not Significant \\
\hline 12 & 500 & 3.68 & 0.54 & 1000 & 3.71 & 0.38 & 1.00 & Not Significant \\
\hline 13 & 500 & 3.96 & 0.88 & 1000 & 3.80 & 0.95 & 1.78 & Not Significant \\
\hline 14 & 500 & 3.76 & 0.61 & 1000 & 3.66 & 0.71 & 1.43 & Not Significant \\
\hline 15 & 500 & 4.71 & 0.45 & 1000 & 4.45 & 1.05 & 1.02 & Not Significant \\
\hline 16 & 500 & 4.01 & 1.29 & 1000 & 4.75 & 0.74 & 0.21 & Not Significant \\
\hline 17 & 500 & 3.92 & 0.58 & 1000 & 3.87 & 0.89 & 0.88 & Not Significant \\
\hline 18 & 500 & 3.90 & 0.89 & 1000 & 3.84 & 1.05 & 0.63 & Not Significant \\
\hline 19 & 500 & 3.11 & 0.38 & 1000 & 3.81 & 0.89 & 1.38 & Not Significant \\
\hline 20 & 500 & 3.73 & 1.18 & 1000 & 3.69 & 1.22 & 0.33 & Not Significant \\
\hline 21 & 500 & 4.00 & 1.39 & 1000 & 4.06 & 0.63 & 0.50 & Not Significant \\
\hline 22 & 500 & 2.52 & 1.05 & 1000 & 2.02 & 0.82 & 0.90 & Not Significant \\
\hline 23 & 500 & 4.68 & 0.32 & 1000 & 4.05 & 0.81 & 0.59 & Not Significant \\
\hline 24 & 500 & 4.33 & 0.83 & 1000 & 3.82 & 1.27 & 0.60 & Not Significant \\
\hline 25 & 500 & 3.80 & 0.98 & 1000 & 3.94 & 0.84 & 0.97 & Not Significant \\
\hline
\end{tabular}

In response to hypothesis 3, Table 6 shows that significant difference does not exist between the mean ratings of trainers and trainees on the current state of apprenticeship system of furniture-making in Edo State. This means that the calculated t-test value of all the 25 items are less than the criterion t-test value of 1.96 at 0.05 level of significance $(\mathrm{P}>0.05)$, thereby retaining the null hypothesis of no significant difference.

\section{Discussion of Findings}

The study revealed that there is good relationship between trainers and trainees. Good relationship helps the learners to have good concentration on the work, more so as the training is through imitation and observation. The trainer does not undergo skill development training. This is not coming as a surprise because many roadside technicians practice by trial and error. Raymond (2007) corroborated this finding when he asserted that the roadside technicians lack professional advancement, which is the reason why many of the technicians could not cope with development in the furnituremaking industries. The findings of this study also revealed that instructions are not systematic. The new apprentice starts learning from the work his master has on hand. The mode of training has no curriculum and the trainees in furnituremaking learn by imitating the trainers. Borga (2008) stated that apprenticeship programmes in plumbing and pipe fitting are guided by some craft union regulations. These regulations limit the number of trainees relative to the trainers. Apprenticeship regulations ensure proper training in the trade, limit membership, regulate earnings of apprentices, offer loans to trainees upon graduation, scholarship programmes for members and their dependents (Borga, 2008). Okorie \& Ezeji (1988); Adeyemi (1999) reported that the apprenticeship system lacks any organized or structure course contents. The learning is limited to what the master trainer knows. The implication is that the training programmes are not universal. There is no cooperation between non-formal apprenticeship system and technical institutions that contribute to deficiency in theory aspect of the training. Ezema (1999) lamented that the apprentices are told what to do but not why they have to do it in the way specified because of lack of theoretical content that can be attributed to why they are unable to deal with situations which are not exactly like the one they have experienced before. The apprentices are also used as domestic servants that cause lack of concentration on the work they came to learn. The certificates issued to trainees on completion of training have no evidence of theoretical work, hours put in and level of performance but participation. This indicates that furniture-making training centres are not scholarly unlike the formal apprenticeship schemes in California, Canada and Germany where trainees are assessed based on training and certificate policies (Harrington \& Merki, 2008). 
Table 2 revealed that apprenticeship training in furnituremaking has some problems against its sustainability and production of skilled labour force for technological development. It is facing numerous problems (Ali \& Okeke, 2000). Olateju (2001) asserted that the state of roadside apprenticeship in Nigeria leaves much to be desired. Some of these problems as revealed by the study, are lack of fund during and after training, low educational qualification of trainers and trainees; poor theoretical emphasis. Ali \& Okeke noted that apprentice training in furniture-making is not organized. Training is carried out through a system that makes the apprentice to copy whatever he/she sees the master doing. In some situations, some selfish trainers are reluctant to pass on the skill to the trainees (Ochiagha, 2005).

The results also revealed that the apprenticeship programme is not receiving the needed attention and support from the government. Olatuju (2001) posited that the roadside craftsmen in Nigeria are neglected by the government. The training is not properly funded. The findings indicated that unsystematic and unplanned content is a big problem to apprenticeship training in furniture-making. As with other types of apprenticeship training programmes. Adeyemi \& Alhassan (1998) posited that the training is bedeviled by many limitations relating to content. Training in furniture-making is unplanned, unstructured and unorganized; knowledge is transmitted through modes like observation, imitation, learning by doing, and trial and error. Findings also revealed that the lack of facilities and equipment affect the quality of training. Many of these apprentices are in low socio-economic class and as a result find it difficult to own some basic tools and equipment. This implies that training is done with only few tools and equipment. Consequently, training may not be efficient and effective.

The results also revealed that government and nongovernmental organizations should collaborate and retrain the trainers. Adeyemi (1999) stressed the need for retraining of trainers so that they can be up to the task in their field. The workshops should be accredited to meet the minimum standard and which also includes supervision of the training programmes. Olateju (2001) opined that the accreditation of the workshops to meet the requirement and constant supervision of programmes to know what kind of skills they are imparting on the apprentices. The findings of the study also revealed the need for cooperation between the non-formal apprenticeship and technical institutions. In line with this finding, Okoro (2006) stated that the apprenticeship system in Nigeria will be more effective if some form of cooperation can be worked out to enable the apprentices receive the theoretical training in the technical colleges.

\section{Conclusion and Recommendations}

The role of artisans and technicians cannot be overemphasized, because of the significant roles they play in the society. The self-employed artisans or technicians that keep the nation's wheel of progress on the move are the products of non-formal apprenticeship system. And as Nigeria desires to become one of the world's largest economies in the world, there is a great need for government and all stakeholders to enhance the development of apprenticeship system in Nigeria. Based on the findings of this study, the following recommendations were made:

1. There is need for increased public awareness of the place of apprenticeship training in manpower development and job creation.

2. Furniture-makers should be encouraged by the government to produce for export through proper funding.

3. The workshop use for training the apprentice should be accredited by the relevant ministry before allowing apprenticeship system and also there should be constant monitoring of the training apprentices receive.

4. A formal cooperation should be formed between nonformal apprenticeship system and technical colleges as technical instructors can remedy the lack of theoretical content in the training programme of apprentices by given them periodic lectures.

5. Government and all stakeholders should assist the master trainers with interest free loan to enable them equipped their workshops with modern equipment.

\section{References}

[1] Adekola, G. (2013): Traditional Apprenticeship in the Old Africa and Its Relevance to Contemporary Work Practices in Modern Nigerian Communities. British Journal of Education, Society \&Behavioural Science 3 (4): 397-406.

[2] Adeyemi, I., \&Alhassan, I. D. (1998).Apprenticeship system: A panacea for sustainable technology. In: G. D. Momoh (ed.). Issues in curriculum development and innovation's for sustainable technology education in Nigeria (NATT Conference Proceedings) $1-9$.

[3] Akubue, B. (2009). Identification of measurement skills needed in pattern drafting by female dressmakers in Enugu State. Ebonyi technology and vocational education journal. 3 (1), 76-80.

[4] Ali, A., \& Okeke, E. (2000). Traditional apprenticeship an education alternative for technology development in Nsukka. Enugu: City Press Ltd.

[5] Borga, G. J. (2008). Labour Union.Microsoft R student (DVD) Redmond, W. A.

[6] Braide, O. O. (2003). A gathering of stars.An exhibition of fabric designs work. (Brochure), Nigeria: University of Agriculture, Abeokuta.

[7] Burns, J. (2009). The advantages of an apprentice. Apprenticeship education Outreach. Montana labour/ management Alliance. Retrieved on July 2013 from: http://www.career.stateuniversity.com

[8] Erica, S. (2012). Good practices in apprenticeship system: Evidence from an international study. Geneva: ILO. 
[9] Ezema, P. N. (1999). Improving apprenticeship system to enhance technology in Nigeria. In: G. D. Momoh (ed.). Issues in curriculum development and innovation's for sustainable technology education in Nigeria (NATT Conference Proceedings) $17-24$.

[10] Famiwole, R. O., Oke, J. O., \&Amadii, N. S. (2012). Potentials of Vocational and Technical Education: Empowering Youths and Vulnerable Adults for Poverty Reduction in Nigeria. Journal of Science and Management, 1 (2), 2026-6499.

[11] Harrington, J. F. \&Merki, P. (2008). Federal Republic of Germany: Apprenticeship programmes. Microsoft R student (DVD). Redmond, W.A.

[12] Musa, A. (2010). Improved Apprenticeship System as Means for Achieving the Millennium Development Goals in Nigeria. Nigeria Journal of Technology Education, 1 (1), 105-110.

[13] Ndom, G. J. (1999). Stressing minimum theoretical basis for the development of apprenticeship system. In: G. D. Momoh (ed.). Issues in curriculum development and innovation's for sustainable technology education in Nigeria (NATT Conference Proceedings). 54 - 65.

[14] Ochiagha, C. (1995). Theory and practice of career development. Enugu: Snap Press.

[15] Okeke, C. A. (2004). Strategies for the improvement of apprenticeship training in dressmaking occupations in
Anambra State. Unpublished Masters Thesis, Department of Vocational Teacher Education, University of Nigeria, Nsukka.

[16] Okorie, J. U. \& Ezeji, S. C. O. A. (1988). Elements of guidance, vocational and career education. Onitsha: Summer Educational Publishers Ltd.

[17] Okoro, E. N. (2012). Improving students' skill acquisition through industrial technical education in tertiary institutions in Anambra State. Nigerian Vocational Association Journal, 17 (1), 17-22.

[18] Okoro, O. M. (1999). Principles and methods in vocational and technical education. Nsukka: University Trust Publishers Co. Ltd.

[19] Okorie, J. U. (2000). Developing Nigeria's workplace. Calabar: Page Environs Publishers.

[20] Olateju, A. S. O. (2001). Revitalizing the apprenticeship system for sustainable poverty alleviation. In: T. A. G. Oladimeji, O. T. Ibeneme, O. M. Adesope, M. A. Ogunyemi, \& H. M. Tukura (Eds.). Technology education and poverty alleviation in Nigeria. $14^{\text {th }}$ annual NATT conference proceedings. Lagos: Fembis International.

[21] Raymond, E. (2007). Constraints affecting electronics servicing of roadside technicians in Minna metropolis. JONATT 6 (2), 12 - 21. 